\title{
Assessment of genetic diversity in different geographically isolated Alhagi graecorum Boiss. populations using SCoT marker
}

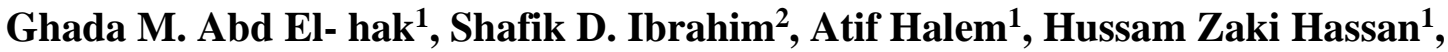 \\ Walaa A. Rayan ${ }^{*}$
}

${ }^{1}$ Botany Department, Faculty of Science, Ain Shams University, Cairo, Egypt.

${ }^{2}$ Agricultural Genetic Engineering Research Institute (AGERI), Agricultural Research

Center, Giza, Egypt.

*Corresponding author: walaagenetics@yahoo.com

\begin{abstract}
The Alhagi genus (commonly known as Camel thorn) belongs to family Fabaceae, has various medicinal properties as revealed by several studies in some diseases treatment. The assessment of genetic diversity within and among Alhagi graecorum populations was carried out using ten SCoT primers. In this study, 25 individuals (five individuals from each population) were sampled, amplified separately and as bulked DNA (DNA from the five samples gathered from each population were bulked together to identify polymorphism among the studied populations). In total, 140 and 156 bands were scored with $71.3 \%$ and 63.7\% polymorphism, respectively. Average polymorphism information content (PIC) for amplified DNA individual of samples was 0.87 and bulked- DNA samples was 0.75 . Analysis of molecular variance (AMOVA) showed that $52 \%$ of the total variation was observed within populations while variation among populations was $48 \%$. The UPGMA cluster analysis divided the 25 individuals and bulked samples into two main groups, each group was further subdivided into many sub-clusters. PCoA was also carried out and in agreement with the UPGMA. The GC values of sequencing for three clearly unique bulked- DNA bands from (SCoT5, SCoT20 and SCoT21) were 54.7, 45.5 and 60.6\%, respectively with average percentage $53.6 \%$. The present results showed the efficiency of SCoT markers for the evaluation of genetic relationships between and among populations due to their efficiency in revealing polymorphism.
\end{abstract}

Key words: Medicinal plant, Alhagi graecorum, Genetic variations, sequencing, SCoT.

\section{INTRODUCTION}

The Alhagi genus belongs to family Fabaceae, which commonly known as Camel thorn or Manna trees. It is wild plant which grows in salty soils and dry environment; it is native in Mediterranean and central Asia regions (Boulos, 1966). This genus comprises different species in the world such as A. pseudalhagi M. Mieb. Desv., A. graecorum Boiss., and A. sparsifolia Shap., etc. (Khan, 2009; Badshah and Hussain, 2011; Xue et al., 2012), these different species of Alhagi have been explored for their antioxidant potential and nutritive value along with various medicinal properties (Muhammad et al., 2015; Ahmed, 2019). Several studies have revealed the use of Alhagi plants in treating a wide spectrum of diseases including gastroenteritis, ulcers, fever, inflammations hypertension and cancer (Zou et al., 2012; Laghari et al., 2012).

Natural products have interesting and useful biological activities and they also perform various functions (Biswas et al., 2010). Researchers are increasingly turning their attention toward natural products in order to develop better drugs against cancer, as well as viral and microbial infections (Revathi and Parimelazhghan, 2010). Since the early days of mankind, plants with secondary metabolites have been used by humans to treat or even protect against infections, health disorders and illness (Wyk and Wink, 2004). Alhagi 


\section{Assessment of genetic diversity}

graecorum is one of these plants which have active constituents such as, flavonoids, fatty acids, coumarins, glycosides, sterols, steroids, resins, vitamins, alkaloids, carbohydrates, tannins, unsaturated sterols and triterpenes (Jack Masquelier, 1996).

Detection of genetic variation and determination of genetic relationships between individuals and populations is an important consideration for the efficient conservation and utilization of plant genetic resources (Henry, 1998; Semagn, et al., 2006). Some studies which were conducted during the last decade of the $20^{\text {th }}$ century reported numerous DNA markers that have been utilized in plant breeding programs (Kordrostami and Rahimi, 2015). Once the generated molecular marker profiles have been evaluated, there are different strategies how to estimate the similarity between the analysed individuals. Similarity indices measure the amount of closeness between two individuals; the larger values are more similar between the two individuals. The development and use of molecular markers for the detection and exploitation of DNA polymorphism is one of the most significant developments in the field of molecular genetics. The presence of various types of molecular markers, and differences in their principles, methodologies, and applications require careful consideration in choosing one or more of such methods (Semagn et al., 2006).

PCR based molecular markers; such as Random Amplified Polymorphic DNA [RAPD (Williams et al., 1990 and Javouhey et al., 2000)], Microsatellites or Simple Sequence Repeat [SSR, (Adawy, et al., 2010 and Ma et al., 2015)], InterSimple Sequence Repeat [ISSR, (Zietkiewicz et al., 1994; Bornet and Branchard, 2001)] are quick, reliable, lower cost and highly informative techniques. So that these techniques are increasingly practical for routine applications to tropical or subtropical species for which very limited research resources are available (Semagn, et al., 2006). DNA marker as SCoT is used efficiently for studying genetic diversity of plants (Collard and Mackill, 2009; Sadek and Ibrahim, 2018). Initiating a trend away from random DNA markers towards gene-targeted markers, this marker system called Start Codon Targeted (SCoT) Polymorphism was developed based on the short conserved region flanking the ATG start codon in plant genes. SCoT markers are generally reproducible, and it is suggested that primer length and annealing temperature are not the sole factors determining reproducibility (Collard and Mackill, 2009).

SCoT markers have been successfully used to evaluate genetic diversity and structure, identify cultivars, and for quantitative trait loci (QTL) mapping and DNA fingerprinting in different species, including wheat, rice, check pea, sugarcane and grape (Collard and Mackill, 2009; Amirmoradi et al., 2012; Guo et al., 2012; Adawy, et al., 2013; Hamidi et al., 2014; Ibrahim et al.,2016). These markers are used with various plant material, among them were; Andrographis paniculata (Tiwari et al., 2016), Vigna unguiculata (Igwe et al., 2017), wheat (Abd El-Lateif and Hewedy, 2018), Trichosanthes dioica Roxb. (Kumar and Agrawal, 2019). Currently, there is no report on genomic DNA isolation and the use of SCoT markers for molecular identification and genetic diversity characterization of collected Alhagi graecorum from Egypt. Therefore, in this study isolation, amplification, and characterization of genomic DNA of twenty five $A$. graecorum genotypes (different five habitats) in Egypt using ten SCoT molecular markers were carried out.

\section{MATERIALS AND METHODS}

\section{Plant material:}

The material comprises 25 genotypes of Alhagi graecorum were collected from different five regions; (1-5) =El-Dakhla Oasis, $(6-10)=$ Botanical garden, Botany 
Department, Ain Shams University, (1115) $=$ Wadi - El Rayan, $(16-20)=$ Qarun Lake and (21-25) = Siwa Oasis.

\section{DNA extraction:}

Genomic DNA was extracted and purified from young leaves of the samples by using $2 \%$ CTAB extraction buffer according to (Doyle and Doyle, 1990). DNA concentrations of total genomic DNA in each sample were estimated using a spectrophotometer (TU 1880 Double Beam UV-VIS). All the DNA samples were stored at $-20{ }^{\circ} \mathrm{C}$.

\section{SCoT -PCR analysis:}

SCoT assay was performed as described in (Collard and Mackill, 2009), for screening was carried out using 10 primers, Table (1).

Table 1: List of primers and their nucleotide Sequences used for SCoT marker in A. graecorum amplification.

\begin{tabular}{lll}
\hline $\begin{array}{l}\text { No. } \\
\end{array}$ & $\begin{array}{l}\text { Primer } \\
\text { code }\end{array}$ & Primer nucleotide sequence $\left(\mathbf{5}^{\prime} \rightarrow \mathbf{3}^{\prime}\right)$ \\
\hline $\mathbf{1}$ & SCoT-4 & 5`ACCATGGCTACCACCGCA 3` \\
$\mathbf{2}$ & SCoT-5 & 5`CAATGGCTACCACTAGCG 3` \\
$\mathbf{3}$ & SCoT-6 & 5`CAATGGCTACCACTACAG 3` \\
4 & SCoT-7 & 5`ACAATGGCTACCACTGAC 3` \\
5 & SCoT-18 & 5`CCATGGCTACCACTAGCA 3` \\
6 & SCoT-19 & 5`CCATGGCTACCACCGGCG 3` \\
7 & SCoT-20 & 5`CAACAATGGCTACCACGC 3` \\
8 & SCoT-21 & 5`CCATGGCTACCACCGGCC 3` \\
9 & SCoT-23 & 5`CATGGCTACCACCGGCCC 3` \\
10 & SCoT-24 & 5`CCATGGCTACCACCGCAG 3` \\
\hline
\end{tabular}

SCoT-PCR reactions were conducted using anchored primers, which were synthesized by Eurofins, Germany. Amplification was performed in a Gene Amp ${ }^{\circledR}$ PCR System 9700 thermal cycler (Applied Bio-systems) programmed using the temperature conditions as shown in Table (2). Electrophoresis of DNA samples were performed on $1.7 \%$ agarose gel and visualized with $0.5 \mathrm{mg} / \mathrm{ml}$ ethidium bromide. DNA bands were visualized on a UV transilluminator at $302 \mathrm{~nm}$ and photographed by Molecular Imager ${ }^{\circledR}$ Gel $\mathrm{Doc}^{\mathrm{TM}} \mathrm{XR}+$ System with Image Lab ${ }^{\mathrm{TM}}$ Software, Bio-Rad ${ }^{\mathrm{TM}}$. Only the clearest and strongest SCoT bands were scored manually as present (1) or absent (0) to be used for further analysis.

Table 2: The SCoT -PCR reaction parameters.

\begin{tabular}{lclc}
\hline \multicolumn{1}{c}{ Steps } & Temperature & Time & Cycles \\
\hline Initial denaturation & $94{ }^{\circ} \mathrm{C}$ & $5 \mathrm{~min}$ & 1 \\
Denaturation & $94{ }^{\circ} \mathrm{C}$ & $1 \mathrm{~min}$ & \\
& $50{ }^{\circ} \mathrm{C}$ & $1 \mathrm{~min}$ & 40 \\
Annealing & $72{ }^{\circ} \mathrm{C}$ & $1.5 \mathrm{~min}$ & \\
Extension & $72{ }^{\circ} \mathrm{C}$ & $7 \mathrm{~min}$ & 1 \\
Final extension & & & \\
\hline
\end{tabular}

\section{Bulking DNA}

Aliquots $(10 \mu \mathrm{l})$ of the same concentration of the DNA individuals were mixed into a bulk of DNA representing each region. Hence, the outcome was 5 bulked DNA samples representing the different populations of A.graecorum included in this study. Nine SCoT primers (the same primers applied before except SCoT-7) were used to amplify the bulked DNA samples with the same conditions.

\section{Statistical analysis}

\section{Genetic variation by using AMOVA} analysis:

This performed to estimate the variance components and their significance levels among and within populations using GenALEx program.

\section{Genetic relatedness and cluster analysis:}

The scored binary data generated by SCoT marker was compared to determine the genetic relatedness of the $25 \mathrm{~A}$. graecorum genotypes. Similarity matrices and cluster analyzing for SCoT markers were performed individually as well as collectively. The SCoT binary matrices were processed using the Bio-Rad diversity database software package and converted into similarity matrices according to Dice 


\section{Assessment of genetic diversity}

coefficient (Dice, 1945; Sneath and Sokal, 1973). The formula used by Dice to estimate the genetic similarity coefficient (GS) between two genotypes was as follows:

\section{Dice formula: $G S i j=2 a /(2 a+b+c)$}

Where GSij is the measure of genetic similarity between individuals $\mathrm{i}$ and $\mathrm{j}$, (a) is the number of bands shared by $i$ and $j$, (b) is the number of bands present in $\mathrm{i}$ and absent in $\mathrm{j}$, and (c) is the number of bands present in $\mathrm{j}$ and absent in $\mathrm{i}$.

\section{Principal coordinates analysis (PCoA):}

Also known as classical multidimensional scaling which is a set of data analyses that show the structure of complex distance-like data represented in a high dimensional space into the lowest possible dimensional space. Prinicipal coordinates analysis (PCoA) resembles principal component analysis (PCA) but it takes dissimilarity as input (Pavoine et al., 2004; Gower, 2015). PCoA was performed based on the matrix calculated for each marker using PAST software (Hammer $\boldsymbol{e t}$ al., 2001).

\section{Sequencing:}

Three unique fragments were selected from bulked DNA for sequencing. DNA sequencing reactions were performed using ABI PRISM Big Dye terminator cycle sequencing ready reaction kit (PE Applied Biosystems, Foster City, California, USA), in conjunction with ABI PRISM (310 Genetic Analyzer). Cycle sequencing was performed using the GeneAmp ${ }^{\circledR}$ PCR System 9700 instrument, and the reaction was conducted in a total volume of $20 \mu \mathrm{l}$, containing $8 \mu \mathrm{l}$ of terminator ready reaction mix, 100-500 ng of PCR product, and 2 pmol of M13 universal forward primer (provided with the kit). The cycle sequencing program was set at $96^{\circ} \mathrm{C}$ for 2 $\min$ ( 1 cycle); $\left(96^{\circ} \mathrm{C}\right.$ for $10 \mathrm{sec}, 50^{\circ} \mathrm{C}$ for 10 sec, and $60^{\circ} \mathrm{C}$ for $4 \mathrm{~min}$, repeated for 25 cycles); $60^{\circ} \mathrm{C}$ for $2 \mathrm{~min}$ (1 cycle), with rapid thermal ramping. The nucleotide sequence was determined automatically by the electrophoresis of the cycle sequencing reaction product on 310 Genetic Analyzer. The data were provided as fluorometric scans from which the sequence was assembled using the sequence analysis software.

\section{Sequence analysis:}

Nucleotide sequences were analysed for homology to nucleotide sequences in GenBank non-redundant databases using the BLAST program (http://www.ncbi.nlm.nih.gov).

\section{RESULTS AND DISCUSSION}

Characterization of the capability of
each SCoT primer to detect
polymorphism

The percentage of polymorphism detected among Alhagi samples gathered from different five regions using the ten SCoT primers was shown in Table (3) and Figure (1). The maximum polymorphism percentage for SCoT-4, SCoT-5 and SCoT6 reached to $68.75 \%, 83.33 \%$ and $77.78 \%$, in Qarun Lake, Wadi El-Rayan and Siwa Oasis, respectively when compared with other regions, also in SCoT-7 the maximum polymorphism was in Qarun Lake (66.67\%). On the other hand, the highest values of polymorphism of each primers; SCoT-18, SCoT-19 and SCoT-20 were recorded $36.36 \%, 58.3 \%$ and $54.5 \%$ in Siwa Oasis, Wadi El-Rayan and Qarun Lake, respectively but the polymorphism percentage for SCoT-21 and SCoT-23 reached to $57.1 \%$ and $50 \%$ for both Siwa Oasis and Qarun Lake respectively. SCoT24 recorded $50 \%$ in all different regions except El-Dakhla Oasis which showing no polymorphism (Table 3). SCoTs are important markers which more stable, produce more reproducible and reliable bands and can be used effectively for population studies, genetic mapping in different plants and in the marker assisted selection programs (Collard and Mackill, 2009). These markers are directly involved in relation of gene function and can be 
Table 3: The percentage of polymorphism recorded by the ten SCoT primers of $A$. graecorum genotypes collected from five locations.

\begin{tabular}{|c|c|c|c|c|c|}
\hline Primer code & Location & $\begin{array}{l}\text { Total no. of } \\
\text { bands }\end{array}$ & $\begin{array}{l}\text { Monomorphic } \\
\text { bands }\end{array}$ & $\begin{array}{l}\text { Polymorphic } \\
\text { bands }\end{array}$ & $\begin{array}{c}\text { Percentage of } \\
\text { polymorphism (\%) }\end{array}$ \\
\hline \multirow{5}{*}{ SCoT-4 } & El-Dakhla oasis & 12 & 6 & 5 & 50.00 \\
\hline & Ain Shams university & 15 & 13 & 2 & 13.33 \\
\hline & Wadi El-Rayan & 16 & 7 & 9 & 56.25 \\
\hline & Qarun lake & 16 & 5 & 11 & 68.75 \\
\hline & Siwa Oasis & 17 & 6 & 11 & 64.71 \\
\hline \multirow{5}{*}{ SCoT-5 } & El-Dakhla oasis & 5 & 2 & 3 & 60.00 \\
\hline & Ain Shams university & 12 & 6 & 6 & 50.00 \\
\hline & Wadi El-Rayan & 12 & 2 & 10 & 83.33 \\
\hline & Qarun lake & 15 & 3 & 12 & 80.00 \\
\hline & Siwa Oasis & 11 & 4 & 7 & 63.64 \\
\hline \multirow{5}{*}{ SCoT-6 } & El-Dakhla oasis & 5 & 4 & 1 & 20.00 \\
\hline & Ain Shams university & 10 & 9 & 1 & 10.00 \\
\hline & Wadi El-Rayan & 8 & 4 & 4 & 50.00 \\
\hline & Qarun lake & 9 & 5 & 4 & 44.44 \\
\hline & Siwa Oasis & 9 & 2 & 7 & 77.78 \\
\hline \multirow{5}{*}{ SCoT-7 } & El-Dakhla oasis & 7 & 3 & 2 & 57.00 \\
\hline & Ain Shams university & 8 & 8 & 0 & 00.00 \\
\hline & Wadi El-Rayan & 9 & 4 & 5 & 55.56 \\
\hline & Qarun lake & 12 & 4 & 8 & 66.67 \\
\hline & Siwa Oasis & 9 & 6 & 3 & 33.33 \\
\hline \multirow{5}{*}{ SCoT-18 } & El-Dakhla oasis & 6 & 5 & 1 & 16.67 \\
\hline & Ain Shams university & 11 & 9 & 2 & 18.18 \\
\hline & Wadi El-Rayan & 10 & 7 & 3 & 30.00 \\
\hline & Qarun lake & 9 & 6 & 3 & 33.33 \\
\hline & Siwa Oasis & 11 & 7 & 4 & 36.36 \\
\hline \multirow{5}{*}{ SCoT-19 } & El-Dakhla oasis & 8 & 5 & 3 & 37.50 \\
\hline & Ain Shams university & 10 & 6 & 4 & 40.00 \\
\hline & Wadi El-Rayan & 12 & 5 & 7 & 58.30 \\
\hline & Qarun lake & 13 & 6 & 7 & 53.9 \\
\hline & Siwa Oasis & 9 & 7 & 2 & 22.22 \\
\hline \multirow{5}{*}{ SCoT-20 } & El-Dakhla oasis & 6 & 5 & 1 & 16.70 \\
\hline & Ain Shams university & 10 & 9 & 1 & 10.00 \\
\hline & Wadi El-Rayan & 10 & 10 & 0 & 0.00 \\
\hline & Qarun lake & 11 & 5 & 6 & 54.55 \\
\hline & Siwa Oasis & 11 & 8 & 3 & 27.27 \\
\hline \multirow{5}{*}{ SCoT-21 } & El-Dakhla oasis & 7 & 6 & 1 & 14.29 \\
\hline & Ain Shams university & 7 & 7 & 0 & 00.00 \\
\hline & Wadi El-Rayan & 8 & 4 & 4 & 50.00 \\
\hline & Qarun lake & 8 & 4 & 4 & 50.00 \\
\hline & Siwa Oasis & 14 & 6 & 8 & 57.14 \\
\hline \multirow{5}{*}{ SCoT-23 } & El-Dakhla oasis & 7 & 5 & 2 & 28.57 \\
\hline & Ain Shams university & 10 & 10 & 0 & 00.00 \\
\hline & Wadi El-Rayan & 10 & 9 & 1 & 10.00 \\
\hline & Qarun lake & 10 & 5 & 5 & 50.00 \\
\hline & Siwa Oasis & 10 & 7 & 3 & 30.00 \\
\hline \multirow{5}{*}{ SCoT-24 } & El-Dakhla oasis & 4 & 4 & 0 & 00.00 \\
\hline & Ain Shams university & 8 & 4 & 4 & 50.00 \\
\hline & Wadi El-Rayan & 10 & 5 & 5 & 50.00 \\
\hline & Qarun lake & 8 & 4 & 4 & 50.00 \\
\hline & Siwa Oasis & 8 & 4 & 4 & 50.00 \\
\hline
\end{tabular}



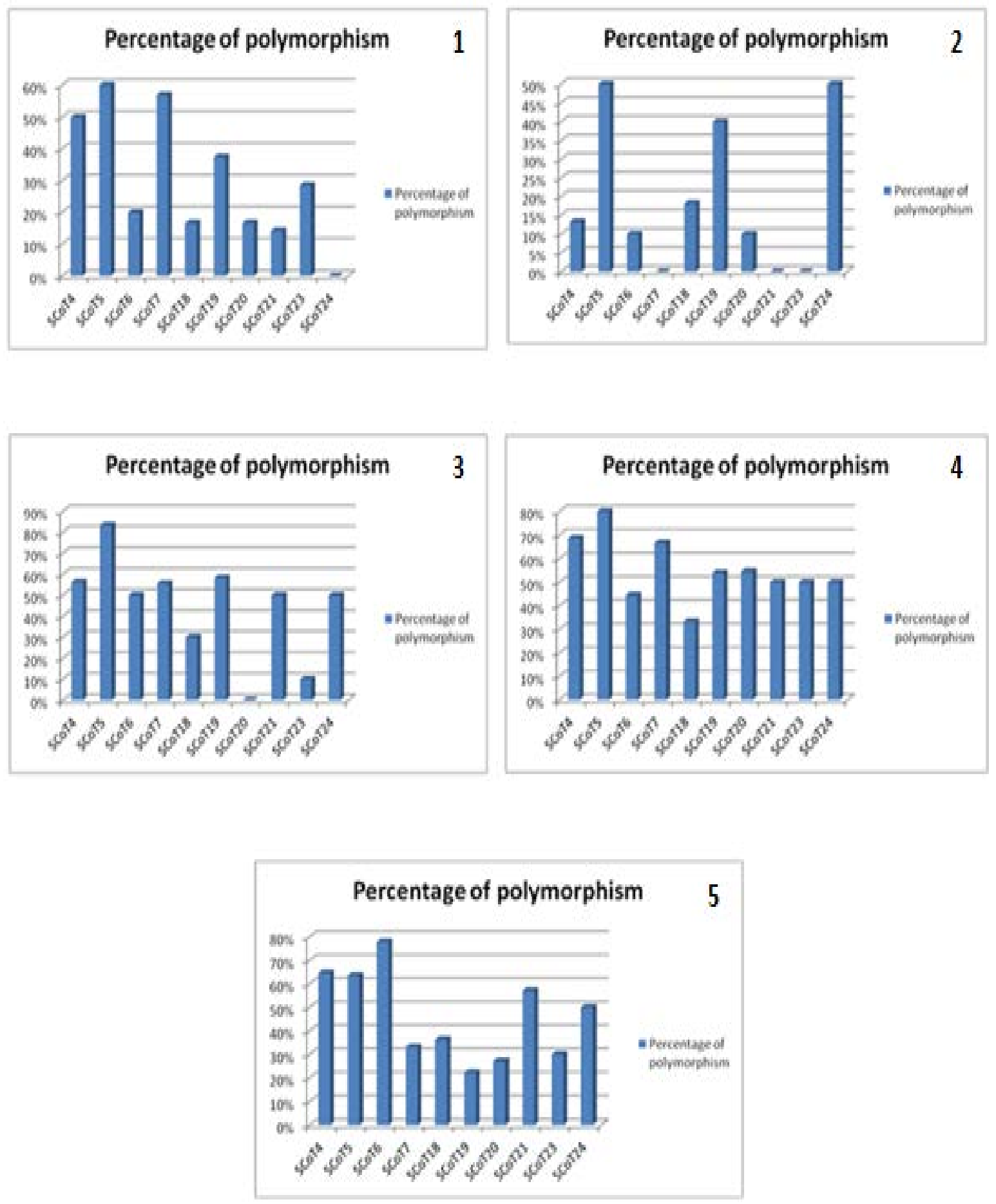

Figure 1: The polymorphism values detected by the ten SCoTprimers among Alhagi samples gathered from 1=El-Dakhla Oasis; 2=Ain Shams University; 3=Wadi El-Rayan; 4=Qarun Lake and $5=$ Siwa Oasis. 
utilized in genotyping and to explore polymorphism (Gorji et al., 2011 and Poczai et al., 2013). Start codon targeted polymorphism technique can be employed to identify DNA polymorphisms, studying genetic diversity and relationships among Alhagi genotypes as used for Arachis hypogaea (Xiong et al., 2011); they ranged polymorphism per primer from 14.29 to $66.67 \%$ with an average of $36.76 \%$. Also, in mango germplasm generated 273 bands with an average of 8.27 bands per primer among the 50 accessions, of which 208 bands were polymorphic (Luo et al., 2010). In another study, a total of 289 bands were generated in Dactylis glomerata and 272 bands were polymorphic, with an average value of 12.95 per primers which ranged between seven to 20 bands (Yan et al., 2016). As well as, ten SCoT primers were screened by Talebi et al. (2018), the total of 73 bands were generated in Cartamus tinctorious, with $83 \%$ polymorphism out of which 61 bands. The maximum and minimum number of polymorphic bands were obtained using SCoT35 (11 bands) and SCoT22 (3 bands), respectively. Similar work, 27 SCoT primers were used by Yang et al. (2019), 419 fragments from a total 429 were polymorphic in Miscanthus lutarioriparius populations. For each SCoT primer, the number of polymorphic fragments ranged from 7 (ST15) to 21 (ST27, 32), with an average of 15.52, whereas, the percentage of polymorphic fragments was f1 `rom $88.89 \%$ to $100.00 \%$. Furthermore, many other studies were employed different SCoT primers to study the genetic diversity for many plant populations such as Dendrobium nobile (Bhattacharyya et al., 2013) and Jojoba genotypes (Heikrujam et al., 2015).

\section{Genetic diversity of individuals and bulked-samples DNA in A. graecorum as revealed by SCoT markers}

The percentage of polymorphism was recorded by the ten SCoT primers among the different $A$. graecorum genotypes (125) collected from different five locations was shown in Table (4) and Figure (2). A total of 140 bands were amplified among the 25 individuals including 37 monomorphic DNA fragments and 103 were polymorphic with percentage $71.3 \%$, four of them are unique bands, whereas the number of polymorphic amplicons varied from 5 to 18 for SCoT-23 and SCoT-5, respectively; but the percentage of the polymorphism were varied between 50\% and 90\% with SCoT-23 and SCoT-5, respectively (Table 4). The SCoT fingerprinting patterns revealed by the nine primers used among the five studied Alhagi populations (bulked- DNA samples) are showed in Figure (3). The genetic polymorphism revealed by the SCoTprimers between the five Alhagi populations, which yielded total number of 156 bands; 54 of them were monomorphic bands and 102 were polymorphic with 39 unique bands and average percentage $63.7 \%$ (Table 5). The number of polymorphic bands varied from 7 to 23 with SCoT-19, SCoT-23 and SCoT-5, respectively but the percentage of the polymorphism were varied between $42 \%$ and $85 \%$ with SCoT-18 and SCoT-5, respectively. Start Codon Targeted (SCoT) markers were used for studying the genetic diversity and relationships within and among Alhagi populations. The level of polymorphism produced in this study was relatively higher than that reported in Lycopersicum esculentum accessions (36.14\%) by using 10 SCoT primers (Shahlaei et al., 2014) and $49.4 \%$ in Jojoba genotypes by using 15 SCoT primers (Heikrujam et al., 2015). The present results in agreement with Luo et al. (2010, 

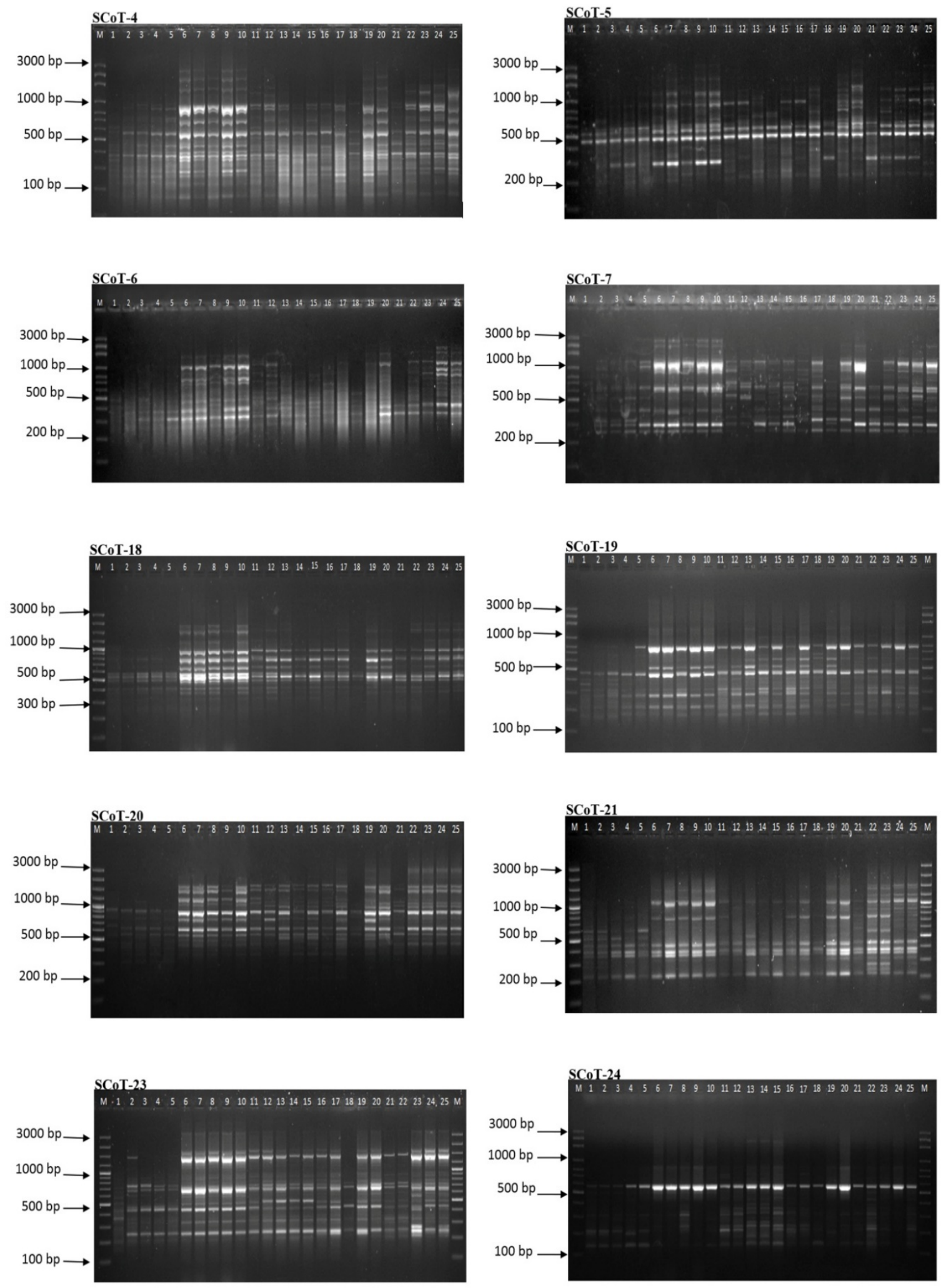

Figure 2: Agarose gel electrophoresis of PCR amplicons using ten SCoT primers to genetically characterize A. graecorum genotypes numbered (1-25). M refers to DNA marker 100 bp plus. 


\section{Assessment of genetic diversity}

2011) they reported that, the percentage of polymorphism were $76.19 \%$ and $65.82 \%$, respectively in mango germplasm accessions. Also, many investigators recorded higher percentages of polymorphism for different plant populations such as $96.21 \%$ on Dendrobium nobile (Bhattacharyya et al., 2013), $92.20 \%$ on Trichosanthes dioica (Kumar and Agrawal, 2019) and 97.67\% on Miscanthus lutarioriparius (Yang et al., 2019).

The polymorphic information content (PIC) varied from 0.654 to 0.955 values where the SCoT-23 had the lowest PIC value while primer SCoT-5 had the highest value with average 0.87 (Table 4). On the other hand, the lowest value of polymorphic information content (PIC) among different SCoT primers in bulked DNA samples was 0.672 in both SCoT 20 and SCoT 23, but the largest value was recorded in the other primers 0.768 with average 0.75 (Table 5). Polymorphic information content (PIC) values of a primer help in determining its effectiveness in genetic diversity analysis (Sivaprakash et al., 2004). They suggested that the ability of the marker system to resolve genetic variation may be more directly related to the degree of polymorphism. Their efficiency was evident from high values of polymorphic percentage and average number of polymorphic bands per primer. The efficiency of SCoT markers has been tested to determine the polymorphic information content for Alhagi genotypes within and among populations then compared with different studies. Similar to the present results, higher mean of PIC $(>0.5)$ ranged from 0.42 to 0.92 with an average of 0.78 were produced by Agarwal et al. (2018) for 29 rose germplasms. In Dendrobium nobile, Bhattacharyya et al. (2013) observed higher PIC value of 0.78 using SCoT marker system, also Satya et al. (2015) recorded higher PIC value of 0.69 using the same marker to assess genetic diversity of Boehmeria nivea. Furthermore, the PIC value of Alhagi was higher when compared with Trichosanthes dioica of 0.45 (Kumar and Agrawal, 2019), Miscanthus lutarioriparius; the (PIC) values were from 0.22 to 0.29 , with an average of 0.26 (Yang et al., 2019). Other plants were recorded lower PIC than the present results, such as Tiwari et al. (2016) studied the genetic relationships among Andrographis paniculata collected from five agroecological regions using SCoT markers; the PIC ranged from 0.09 to 0.48 , with an average value of 0.34. Alikhani et al. (2014) and Heikrujam et al. (2015) showed the PIC by using SCoT markers for Quercus brantii and Simmondsia chinensis, respectively was 0.38 . Furthermore, Talebi et al. (2018) recorded that; the PIC average value was 0.39 for safflower genotypes using SCoT technique.

The molecular variance (AMOVA) was used to estimate the genetic variability within and among populations (Table 6), being most of the genetic diversity found within the populations (52\%). The genetic variation levels among different populations is due to environmental change conditions (Lovejoy and Hannah, 2005) and populations with low variability are generally considered less adapted under adverse circumstances. Therefore, the assessment of genetic diversity in geographically isolated populations is very valuable for identification of low diverse populations. The histories of species and reproductive systems have direct influence on the distribution and levels of genetic variation, genetic divergence, and genetic structure (Hamrick and Godt, 1996; Segarra-Moragues and Catalan, 2002). In this study, the genetic variation within and among populations by using the AMOVA analysis and SCoT technique is similar to many studies such as Zhang et al. (2015) who estimated the genetic diversity and relationships among Chinese Elymus sibiricus accessions and showed greater genetic variation within geographical regions (50.99\%) than among them (49.01\%). Furthermore, Jiang et al. (2014) demonstrated that, orchard grass 
Table 4: SCoT primer names, total number of bands, polymorphic bands, monomorphic bands, percentage of polymorphism, unique bands, fragment size range and polymorphic information content (PIC) as revealed by SCoT analysis of 25 A. graecorum genotypes.

\begin{tabular}{ccccccccc}
\hline S. & $\begin{array}{c}\text { Primer } \\
\text { code }\end{array}$ & $\begin{array}{c}\text { Total } \\
\text { no. of } \\
\text { bands }\end{array}$ & $\begin{array}{c}\text { Polymorphic } \\
\text { bands }\end{array}$ & $\begin{array}{c}\text { Monomorphic } \\
\text { bands }\end{array}$ & $\begin{array}{c}\text { Percentage of } \\
\text { polymorphism } \\
\text { (POL \%) }\end{array}$ & $\begin{array}{c}\text { Unique } \\
\text { bands }\end{array}$ & $\begin{array}{c}\text { Fragment } \\
\text { size range } \\
\text { (bp) }\end{array}$ & PIC \\
\hline $\mathbf{1}$ & SCoT-4 & 21 & 17 & 4 & 80.9 & - & $2312-154$ & 0.948 \\
$\mathbf{2}$ & SCoT-5 & 20 & 18 & 2 & 90 & 2 & $2713-201$ & 0.955 \\
$\mathbf{3}$ & SCoT-6 & 11 & 9 & 2 & 81.8 & - & $2138-247$ & 0.884 \\
$\mathbf{4}$ & SCoT-7 & 13 & 10 & 3 & 76.9 & 1 & $2351-255$ & 0.9 \\
$\mathbf{5}$ & SCoT-18 & 12 & 7 & 5 & 58 & - & $2047-320$ & 0.88 \\
$\mathbf{6}$ & SCoT-19 & 15 & 11 & 4 & 73 & 1 & $1634-150$ & 0.92 \\
$\mathbf{7}$ & SCoT-20 & 11 & 6 & 5 & 54.5 & - & $2757-289$ & 0.789 \\
$\mathbf{8}$ & SCoT-21 & 16 & 12 & 4 & 75 & - & $1848-214$ & 0.869 \\
$\mathbf{9}$ & SCoT-23 & 10 & 5 & 5 & 50 & - & $3063-196$ & 0.654 \\
$\mathbf{1 0}$ & SCoT-24 & 11 & 8 & 3 & 72.7 & - & $2044-119$ & 0.868 \\
\hline & Total & $\mathbf{1 4 0}$ & 103 & 37 & & $\mathbf{4}$ & \\
\hline
\end{tabular}
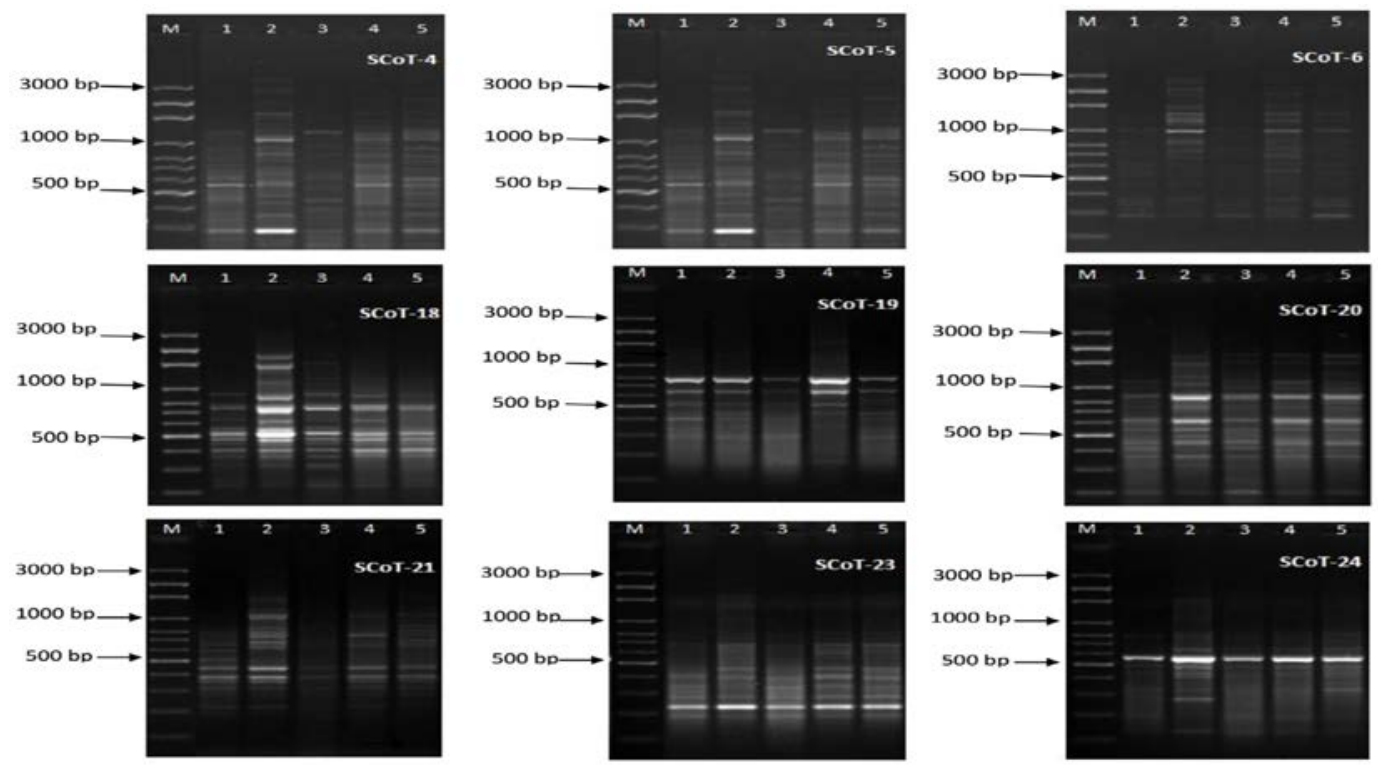

Figure 3: SCoTs profiles (4, 5, 6, 18, 19, 20, 21, 23 and 24) for A. graecorum populations (DNA bulked samples). M refers to DNA ladder (100 bp) plus. A. graecorum populations are $1=$ El-Dakhla Oasis; 2 = Ain Shams University; 3 = Wadi El-Rayan; 4 = Qarun Lake; 5 = Siwa Oasis. 
Table 5: Total number of bands, polymorphic bands, monomorphic bands, percentage of polymorphism, unique bands, fragment size range and polymorphic information content (PIC) as revealed by SCoT analysis among $A$. graecorum populations (DNA bulked samples).

\begin{tabular}{|c|c|c|c|c|c|c|c|c|}
\hline S. & $\begin{array}{c}\text { Primer } \\
\text { name }\end{array}$ & $\begin{array}{l}\text { Total } \\
\text { no. of } \\
\text { bands }\end{array}$ & $\begin{array}{c}\text { Polymorphic } \\
\text { bands }\end{array}$ & $\begin{array}{l}\text { Monomorphic } \\
\text { bands }\end{array}$ & $\begin{array}{c}\text { Percentage of } \\
\text { polymorphism } \\
\text { (POL \%) }\end{array}$ & $\begin{array}{l}\text { Unique } \\
\text { bands }\end{array}$ & $\begin{array}{c}\text { Fragment } \\
\text { size range } \\
\text { (bp) }\end{array}$ & PIC \\
\hline 1 & SCoT-4 & 18 & 12 & 6 & 66.7 & 4 & $3082-229$ & 0.768 \\
\hline 2 & SCoT-5 & 27 & 23 & 4 & 85 & 7 & $2790-278$ & 0.768 \\
\hline 3 & SCoT-6 & 20 & 16 & 4 & 80 & 6 & 2030-329 & 0.768 \\
\hline 4 & SCoT-18 & 19 & 8 & 11 & 42 & 4 & $1572-244$ & 0.768 \\
\hline 5 & SCoT-19 & 11 & 7 & 4 & 63.6 & 4 & 1251-203 & 0.768 \\
\hline 6 & SCoT-20 & 17 & 8 & 9 & 47 & 6 & 1526-218 & 0.672 \\
\hline 7 & SCoT-21 & 17 & 12 & 5 & 70.6 & 2 & 1324-203 & 0.768 \\
\hline 8 & SCoT-23 & 14 & 7 & 7 & 50 & 3 & $1464-216$ & 0.672 \\
\hline 9 & SCoT-24 & 13 & 9 & 4 & 69.2 & 3 & 549-161 & 0.768 \\
\hline & Total & 156 & 102 & 54 & & 39 & & \\
\hline & Average & 17.3 & 11.3 & 6 & 63.7 & & & 0.75 \\
\hline
\end{tabular}

Table 6: Analysis of molecular variance (AMOVA) for nine SCoT markers among A. graecorum populations.

\begin{tabular}{cccccc}
\hline $\begin{array}{c}\text { Source of } \\
\text { variations }\end{array}$ & $\begin{array}{c}\text { Degree of } \\
\text { freedom }\end{array}$ & $\begin{array}{c}\text { Sum of } \\
\text { squares }\end{array}$ & $\begin{array}{c}\text { Mean } \\
\text { square }\end{array}$ & $\begin{array}{c}\text { Variance } \\
\text { components }\end{array}$ & $\begin{array}{c}\% \text { of total } \\
\text { variance }\end{array}$ \\
\hline $\begin{array}{c}\text { Among } \\
\text { populations } \\
\text { Within } \\
\text { populations }\end{array}$ & 4 & 230.16 & 57.54 & 9.48 & $48 \%$ \\
Total & 20 & 202.00 & 10.10 & 10.100 & $52 \%$ \\
\hline
\end{tabular}


germplasms had a higher level of genetic variance within groups (69.13) than among geographical regions and distributions (30.87\%), suggesting a high discriminating ability of the SCoT technique for this plant. Similar to the present results, Yang et al. (2019) showed that variation by using SCoT primers was more abundant within Miscanthus lutarioriparius populations (84.91\%) than among them (15.09). In contrast, there are many investigators observed higher molecular variation among populations than within them; Al-Qurainy et al. (2015) showed higher molecular variation (52\%) among the date palm populations, whereas $48 \%$ was found within the populations. Also, Bhattacharyya et al. (2013) analyzed the genetic variation among the Dendrobium nobile populations $56.63 \%$, whereas $43.37 \%$ was recorded within them. Different factors such as mating system Charlesworth and Wright (2001), gene flow Hamrick and Godt (1996), population size, selection, etc. influence genetic diversity levels within populations. Out- crossing plant species keep together new genes combinations rapidly and commonly have high genetic diversity. Short lived perennials plant species are considered to be less genetically diverse than long lived ones.

Genetic similarities matrix of $A$. graecorum as revealed by SCoT markers

Table (7) showed that, the estimated similarities among the 25 Alhagi genotypes ranged from 0.6 to 0.99 . The highest genetic similarity (0.99) was between genotypes 6 and 7 (both of them from Ain Shams University), while the lowest genetic similarity (0.6) was between each of the following genotypes 19 (individual from Qarun Lake) and 4 (individual from El-Dakhla Oasis), 1 (individual from ElDakhla Oasis) and 23 (individual from Siwa Oasis), and 1 (individual from ElDakhla Oasis) and 24 (individual from
Siwa Oasis). The similarity index resulted from SCoT scoring for the five $A$. graecorum populations were shown in Table (8). The estimated similarities ranged from 0.65 to 0.87 . The highest similarity value (0.87) was recorded between both Qarun Lake and Siwa Oasis populations; this indicated that these two populations closely related to each other. On the other hand, the lowest similarity value (0.65) was recorded between Ain Shams University and Wadi El-Rayan populations, indicating that these were distantly related variety. Similar result obtained by Heikrujam et al. (2015) who recorded similarity co-efficient of SCoT markers ranged from 0.733 to 0.922 in female Simmondsia chinensis genotypes and 0.941 to 0.746 in the male genotype populations, indicating high levels of genetic similarity among the genotypes studied. Also, similarity values according to Jaccard's coefficients of the safflower genotypes based on SCoT molecular markers ranged from 0.49 to 0.93 were reported by Talebi et al. (2018).

\section{Cluster analysis as revealed by SCoT markers and principal coordinates analysis}

The dendrogram obtained from UPGMA cluster analysis of genetic distance based on 10 SCoT primers is shown in Figure (4A). The cluster analysis resolved 25 Alhagi individuals into two main clusters. The first main cluster consisted of population coming from ElDakhla Oasis (1-5), one individual from Siwa Oasis population (21) and other individual from Qarun Lake population (18). Where this cluster can be subdivided into two sub-clusters, the first sub-cluster included all individuals of El-Dakhla Oasis population (1-5) while the second subcluster included the two individuals from Siwa Oasis population (21) and Qarun Lake population (18).The second main cluster consisted of populations coming from Ain 
Table 7: Genetic similarity matrix among the 25 A. graecorum genotypes as computed according to Dice's coefficient as revealed by SCoT markers.

\begin{tabular}{|c|c|c|c|c|c|c|c|c|c|c|c|c|c|c|c|c|c|c|c|c|c|c|c|c|c|}
\hline & 1 & 2 & 3 & 4 & 5 & 6 & 7 & 8 & 9 & 10 & 11 & 12 & 13 & 14 & 15 & 16 & 17 & 18 & 19 & 20 & 21 & 22 & 23 & 24 & 25 \\
\hline 1 & 1 & & & & & & & & & & & & & & & & & & & & & & & & \\
\hline 2 & 0.90 & 1 & & & & & & & & & & & & & & & & & & & & & & & \\
\hline 3 & 0.94 & 0.93 & 1 & & & & & & & & & & & & & & & & & & & & & & \\
\hline 4 & 0.88 & 0.89 & 0.89 & 1 & & & & & & & & & & & & & & & & & & & & & \\
\hline 5 & 0.86 & 0.91 & 0.88 & 0.93 & 1 & & & & & & & & & & & & & & & & & & & & \\
\hline 6 & 0.62 & 0.68 & 0.66 & 0.63 & 0.66 & 1 & & & & & & & & & & & & & & & & & & & \\
\hline 7 & 0.62 & 0.67 & 0.65 & 0.62 & 0.65 & 0.99 & & & & & & & & & & & & & & & & & & & \\
\hline 8 & 0.64 & 0.69 & 0.68 & 0.64 & 0.68 & 0.96 & 0.95 & 1 & & & & & & & & & & & & & & & & & \\
\hline 9 & 0.61 & 0.66 & 0.64 & 0.61 & 0.64 & 0.94 & 0.94 & 0.94 & 1 & & & & & & & & & & & & & & & & \\
\hline 10 & 0.61 & 0.66 & 0.64 & 0.61 & 0.63 & 0.95 & 0.95 & 0.92 & 0.94 & 1 & & & & & & & & & & & & & & & \\
\hline 11 & 0.69 & 0.71 & 0.68 & 0.66 & 0.69 & 0.82 & 0.82 & 0.82 & 0.81 & 0.84 & 1 & & & & & & & & & & & & & & \\
\hline 12 & 0.67 & 0.73 & 0.69 & 0.67 & 0.71 & 0.81 & 0.81 & 0.81 & 0.81 & 0.82 & 0.89 & 1 & & & & & & & & & & & & & \\
\hline 13 & 0.68 & 0.74 & 0.71 & 0.67 & 0.73 & 0.80 & 0.80 & 0.80 & 0.80 & 0.81 & 0.82 & 0.84 & 1 & & & & & & & & & & & & \\
\hline 14 & 0.72 & 0.74 & 0.74 & 0.67 & 0.72 & 0.76 & 0.75 & 0.75 & 0.76 & 0.77 & 0.84 & 0.84 & 0.88 & 1 & & & & & & & & & & & \\
\hline 15 & 0.67 & 0.69 & 0.69 & 0.65 & 0.70 & 0.79 & 0.79 & 0.78 & 0.77 & 0.78 & 0.86 & 0.86 & 0.86 & 0.89 & 1 & & & & & & & & & & \\
\hline 16 & 0.72 & 0.77 & 0.74 & 0.69 & 0.73 & 0.78 & 0.78 & 0.77 & 0.76 & 0.77 & 0.87 & 0.88 & 0.81 & 0.86 & 0.90 & 1 & & & & & & & & & \\
\hline 17 & 0.67 & 0.71 & 0.70 & 0.67 & 0.70 & 0.79 & 0.79 & 0.79 & 0.79 & 0.79 & 0.82 & 0.85 & 0.88 & 0.86 & 0.88 & 0.87 & 1 & & & & & & & & \\
\hline 18 & 0.79 & 0.84 & 0.83 & 0.83 & 0.83 & 0.70 & 0.69 & 0.70 & 0.70 & 0.70 & 0.71 & 0.74 & 0.74 & 0.78 & 0.73 & 0.78 & 0.76 & 1 & & & & & & & \\
\hline 19 & 0.63 & 0.65 & 0.66 & 0.60 & 0.63 & 0.89 & 0.89 & 0.86 & 0.87 & 0.87 & 0.79 & 0.81 & 0.81 & 0.78 & 0.81 & 0.79 & 0.86 & 0.70 & 1 & & & & & & \\
\hline 20 & 0.62 & 0.65 & 0.66 & 0.61 & 0.63 & 0.87 & 0.87 & 0.83 & 0.84 & 0.84 & 0.80 & 0.81 & 0.77 & 0.73 & 0.78 & 0.79 & 0.80 & 0.67 & 0.91 & 1 & & & & & \\
\hline 21 & 0.71 & 0.77 & 0.76 & 0.74 & 0.76 & 0.73 & 0.73 & 0.72 & 0.72 & 0.72 & 0.75 & 0.77 & 0.80 & 0.80 & 0.80 & 0.79 & 0.80 & 0.84 & 0.77 & 0.74 & 1 & & & & \\
\hline 22 & 0.63 & 0.67 & 0.68 & 0.64 & 0.68 & 0.79 & 0.79 & 0.77 & 0.76 & 0.77 & 0.80 & 0.80 & 0.77 & 0.76 & 0.77 & 0.76 & 0.79 & 0.72 & 0.81 & 0.78 & 0.81 & 1 & & & \\
\hline 23 & 0.60 & 0.65 & 0.65 & 0.63 & 0.64 & 0.81 & 0.81 & 0.79 & 0.78 & 0.80 & 0.75 & 0.81 & 0.76 & 0.69 & 0.75 & 0.75 & 0.77 & 0.70 & 0.83 & 0.81 & 0.76 & 0.89 & 1 & & \\
\hline 24 & 0.60 & 0.65 & 0.65 & 0.63 & 0.65 & 0.84 & 0.85 & 0.81 & 0.81 & 0.82 & 0.77 & 0.80 & 0.77 & 0.73 & 0.77 & 0.76 & 0.80 & 0.72 & 0.86 & 0.83 & 0.78 & 0.87 & 0.90 & 1 & \\
\hline 25 & 0.61 & 0.64 & 0.65 & 0.59 & 0.63 & 0.84 & 0.84 & 0.82 & 0.80 & 0.81 & 0.79 & 0.80 & 0.77 & 0.75 & 0.77 & 0.76 & 0.80 & 0.71 & 0.85 & 0.84 & 0.78 & 0.87 & 0.90 & 0.93 & 1 \\
\hline
\end{tabular}

Table 8: Genetic similarity matrix of five A. graecorum populations (bulked DNA samples) as computed according to Dice's coefficient from SCoT data. Alhagi populations are numbered (1-5). 1 = El-Dakhla oasis; 2 = Ain Shams university; 3 = Wadi El-Rayan; 4 = Qarun Lake; 5 = Siwa Oasis.

\begin{tabular}{cccccc}
\hline & $\mathbf{1}$ & $\mathbf{2}$ & $\mathbf{3}$ & $\mathbf{4}$ & $\mathbf{5}$ \\
\hline $\mathbf{1}$ & 1 & & & & \\
$\mathbf{2}$ & 0.68 & 1 & & & \\
$\mathbf{3}$ & 0.78 & $\mathbf{0 . 6 5}$ & 1 & & \\
$\mathbf{4}$ & 0.75 & 0.76 & 0.73 & 1 & \\
$\mathbf{5}$ & 0.77 & 0.79 & 0.72 & $\mathbf{0 . 8 7}$ & 1 \\
\hline
\end{tabular}




\section{Assessment of genetic diversity}

Shams University (6-10), Wadi El-Rayan (11-15) and the remaining individuals coming from Qarun Lake $(16,17,19,20)$ and Siwa Oasis (22-25) populations. This cluster can be subdivided into two subclusters, the first included all Wadi ElRayan population (11-15) and two individuals from Qarun Lake population (16 and 17), while the second sub-cluster included Ain Shams University population (6-10) and the remaining individuals from Qarun Lake (19 and 20) and Siwa Oasis (22-25) populations.

On the other hand, the dendrogram obtained from UPGMA cluster analysis of genetic distance based on nine SCoT markers between the different five populations is showed in Figure (4B). The resulting $\mathrm{SCoT}$ dendrogram showed that the studied populations were differentiated into two clusters. In the first cluster, Ain Shams University population was delimited as a single population in a sub-cluster, while Qarun Lake and Siwa Oasis populations were grouped together as another clade. The second cluster divided into two sub-clusters, Wadi El-Rayan and El-Dakhla populations, each represented by a single clade.

To well comprehend and obtain an alternative view of the relationships among Alhagi genotypes, PCoA was performed using the genetic similarity data sets Figure (5a) showed the scatter plots for PCoA based on SCoT marker data. PCoA was basically similar to the grouping created by UPGMA clustering. The PCoA resulted from SCoT marker classified the 25 Alhagi individuals into 4 groups. Group A comprises four individuals from Siwa Oasis population (22-25), group B comprising Ain Shams University population (6-10) and two individuals from Qarun Lake population (19 and 20), group $C$ having all individuals coming from Wadi El-Rayan (11-15) and two individuals from Qarun Lake population (16 and 17), while the last group D contains all El-Dakhla Oasis individuals (1-5) in addition to individual from Qarun Lake (18) and individual from Siwa Oasis (21) populations. The PCoA was basically similar to the grouping created by UPGMA clustering resulted from SCoT marker Figure (5b). This analysis was classifying the five Alhagi populations into 3 groups; the first one comprising the Ain Shams University population (A) as indicated by cluster analysis, and the second group having ElDakhla Oasis and Wadi El-Rayan populations (B) while the latter (C) comprised Qarun Lake and Siwa Oasis populations. Similar to our results, clustering based on geographical regions has also been seen in different plants such as Arabidopsis thaliana (Tyagi et al., 2016) and Pulsatilla patens (Szczecinska ta al., 2016). The pattern of genetic subdivision can be clearly demonstrated in the UPGMA cluster analysis, in which our results were similar to the Jojoba (Heikrujam et al., 2015) and switchgrass (Zhang et al., 2016) populations which divided into two groups according to their habitat.

Also, Yan et al. (2016) reported that, results from the UPGMA were relative to the geographical distribution of the orchardgrass (Dactylis glomerata L.). Furthermore, Kumar and Agrawal (2019) divided the Trichosanthes dioica accessions into three main clusters by using UPGMA tree. The results of PCoA analysis also support this habitat-specific genetic clustering model obtained by UPGMA similar to many researchers; Talebi et al. (2018) grouped the safflower genotypes into three major groups using SCoT molecular dataset. Also, Zhang et al. (2015) reported that, cluster analysis separated the Elymus sibiricus accessions into two major clusters and three subclusters, similar to results of principal coordinate analysis (PCoA). In addition, Yang et al. (2019) recovered five clear clusters using principal coordinate analysis (PCoA) and an unweighted pair group method with arithmetic mean (UPGMA) 


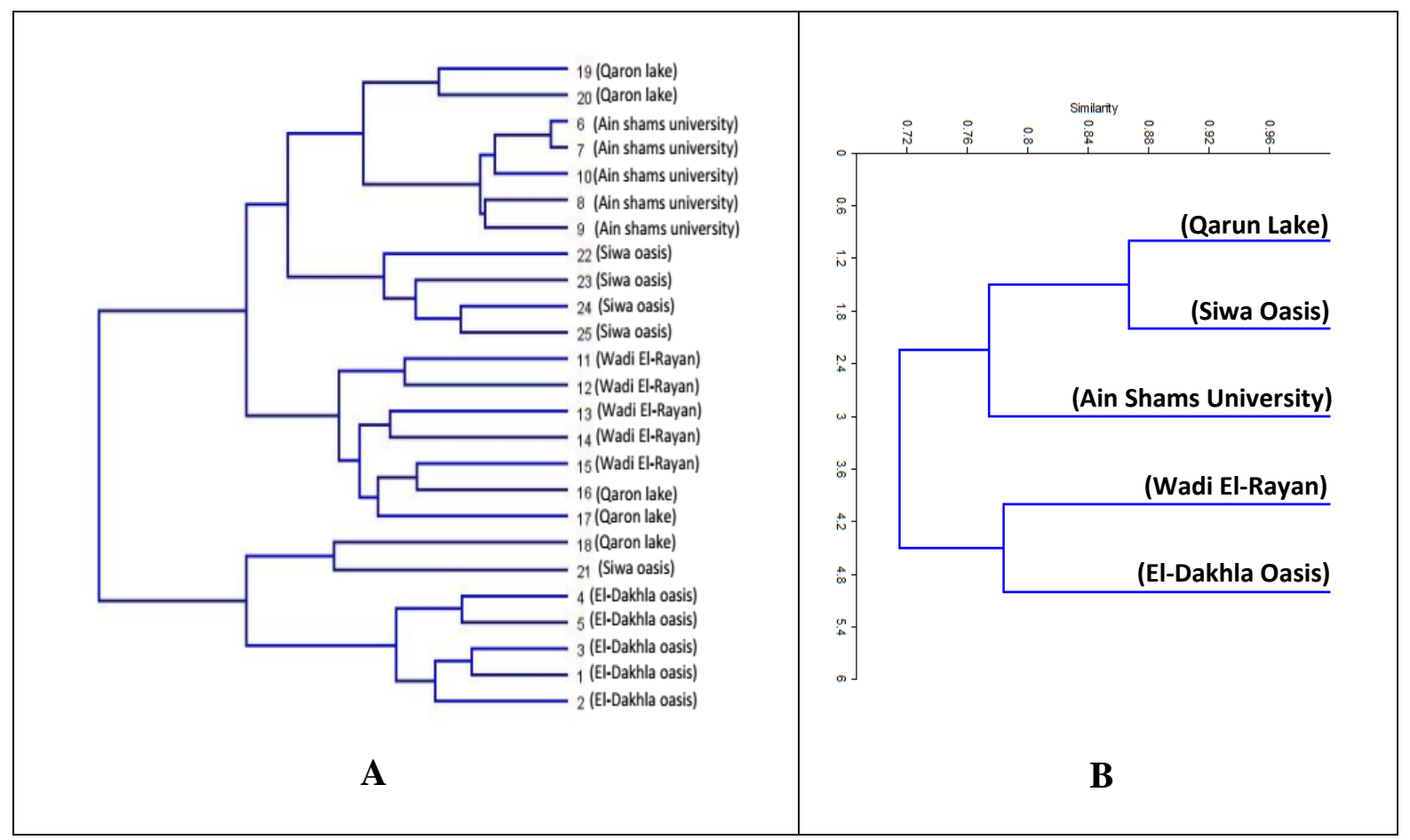

Figure 4: Dendrogram: (A) the 25 A. graecorum genotypes 1-25. (B) the five A. graecorum populations (bulked DNA samples) constructed from the SCoT data using Unweighed Pair-group Arithmetic Average (UPGMA) and similarity matrix computed according to Dice's coefficient. Populations: 1 = El-Dakhla Oasis; 2 = Ain Shams University; 3 = Wadi El-Rayan; 4 = Qarun Lake; 5 = Siwa Oasis.

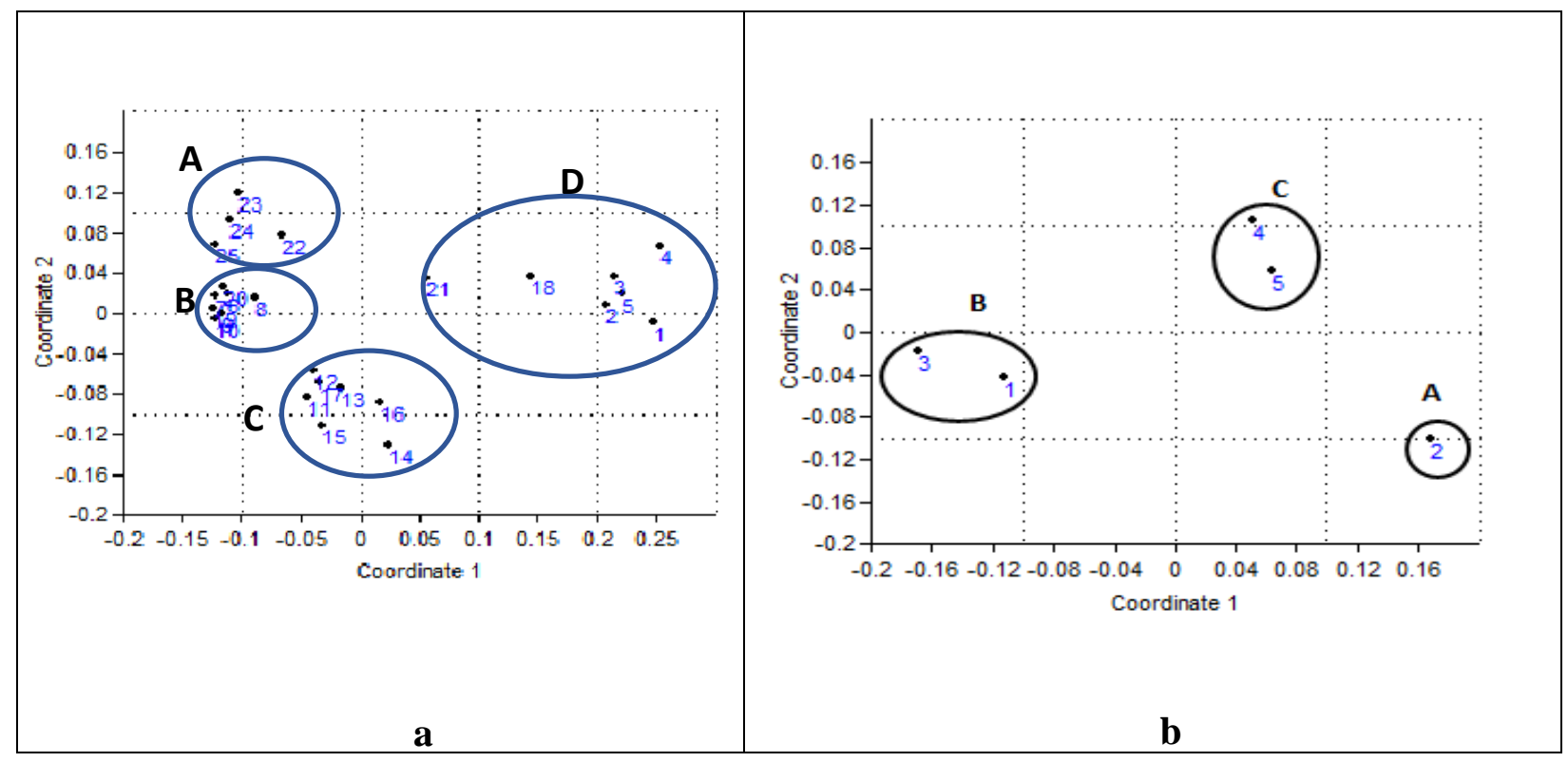

Figure 5: Scatter plot of principal coordinate analysis (PCoA) of a) 25 Alhagi individuals b) 5 Alhagi populations (bulked DNA samples) based on SCoT marker data: 1=El-Dakhla Oasis; 2=Ain Shams University; 3=Wadi El-Rayan; 4=Qarun Lake; 5= Siwa Oasis. 


\section{Ghada M. Abd El- hak et al.}

cluster analysis on Miscanthus lutarioriparius populations.

\section{SCoTs sequencing analysis resulted from bulked DNA samples of Alhagi graecorum}

The amplified unique products obtained using SCoT-5, SCoT-20 and SCoT-21 primers (only primers showing clear and reproducible band patterns) were selected for further analysis were purified and sequenced then aligned. The amplified bands were resulted at molecular sizes 300 , 400 and 700 bp with SCoT-5, SCoT-20 and SCoT-21, respectively (Figure 6). The sequence of these fragments from genomic Alhagi graecorum DNA collected from Wadi EL-Rayan, Ain Shams University and EL-Dakhla Oasis regions, respectively were 578 bp for SCoT-5, 585 bp for SCoT20 and 553 bp for SCoT-21 (Figure 7). Also, Hao et al. (2018) deposited the sequence of the Taxus media-specific fragment of 530 bp fragment in GenBank (GenBank accession number MF447807). The sequence contained 49.25\% A-T and 50.75\% G-C. Based on this sequence, a SCoT-SCAR primer pair was designed, The $T$. media-specific sequence of $530 \mathrm{bp}$ had no homology with other sequences in GenBank. Abdelmaksoud et al. (2009) showed the significant sequence homology of the fragments Vms2-9 \& Vms2-17 of Vicia monantha with ESTs from Saccharum officinarum cDNA under drought stress with E-values 3e-10 \& 3e-11, respectively whereas Fragment Vms5-50 was homology with an EST from Groundnut drought stress with E-value 4e-23, but Fragments Vms1-1 \& Vms2-21 showed homology with Cucumis sativus C-repeat/DRE binding factor 1 (cbf1) with E-values 2e-06 \& 1e06 , respectively.

The comparison between nucleotide sequences of the fragments isolated from genomic Alhagi graecorum DNA and another plants sequence in the Genbank, by alignment the isolated sequence in Genbank by nucleotide blast and blastx (http//blast.ncbi.nlm) was shown in Table (9). The identity percentage of SCoT-5 with a large value in homology with Vigna unguiculata cultivar Xiabao 2 chromosome Vu03 (89.47\%) with accession number CP039346.1 and coverage 8\%, while the large coverage was $12 \%$ in homology with Lupinus angustifolius cultivar Tanjil chromosome LG-11 with accession number CP023123.1 and identity 82.61\%. On the other hand, the identity percentage of SCoT-20 with a large value in homology with Lotus japonicus genomic DNA, chromosome 5, clone: LjT47L09, TM0218, complete sequence (85.71\%) with accession number AP006374.1 and coverage $51 \%$, while the higher coverage recorded 56\% in homology with Lupinus angustifolius cultivar Tanjil chromosome LG-04 with accession number CP023116.1 and identity $82.52 \%$. In case of SCoT-21 the percentage of identity was in higher value in homology with Cytochrome b6 apoprotein of Pisum sativum (28.89\%) with accession number AAD41888.1 and coverage $48 \%$, while the minimum value of identity was found in homology with cytochrome b6 of Medicago truncatula (25\%) with accession number RHN38456.1. Mohamed et al. (2017), studied the sequence analysis of highly pronounced unique polymorphic SCoT amplicons (SCoT-2, SCoT-3, SCoT-11, SCoT-47, and SCoT-48 primers) among the Triticum aestivum L. cultivars followed by analyze unique monomorphic SCoT amplicon obtained with SCoT-8. Forward sequences of the latter SCoT amplicons were aligned and compared by their BLAST scores to published available 


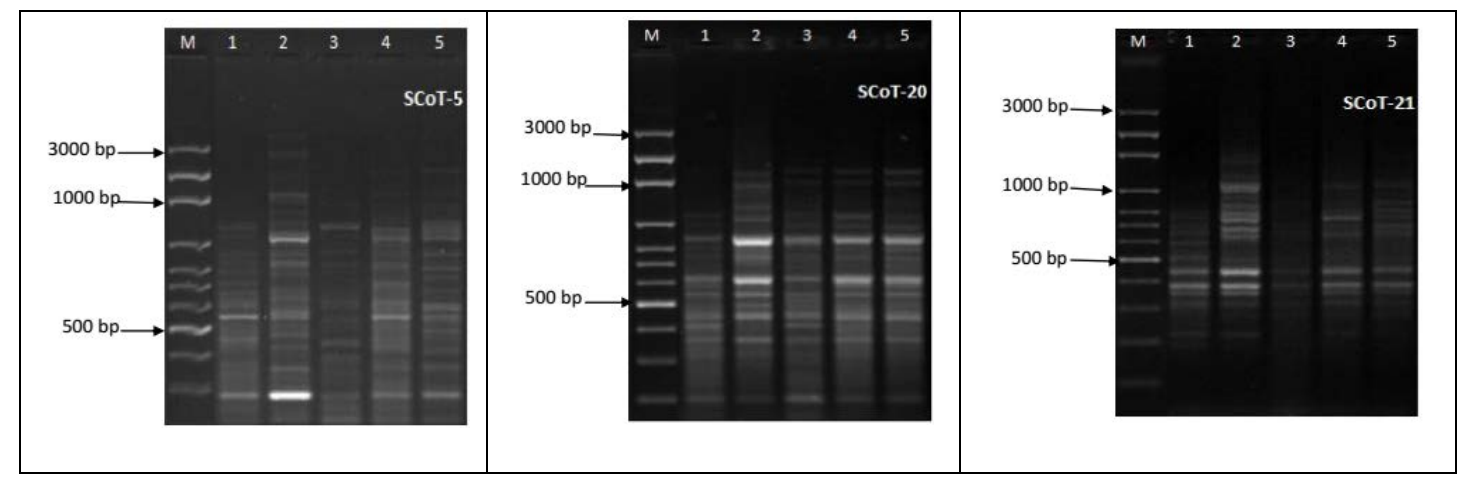

Figure 6: SCoT profiles (SCoTs 5, 20 and 21) for A. graecorum populations. M refers to DNA ladder. 100 bp plus. A. graecorum populations are 1=El-Dakhla Oasis; 2=Ain Shams University; 3=Wadi El-Rayan; 4=Qarun Lake; 5= Siwa Oasis.

GGAAGGCGGGAACCACACATCTCTTTTTTCCCCСCССССССTTTAATATTTTTGTTAGACCCC CCСTTCCTTCСTCTTCGCСACСTTTTTCATCCTCTTCCGGACCGTCTCTGCCCCCCCTGAGGA ATGCGAGGGACAAGCTCAACGCCGTGACCGCTATCCCCACAAGTTTGCGCCTCTTCTGGAAT GGACCGGCTTTTCCTTAGGGGCTCCTTTACCCCGAAAAAATACGCTTCCGGTCGAGGGTGGG AGATGAGGACGCCGGGGGGAGAAGTGATCGGCCGCGTGGGGAGGAGGGGGGCGCAAGTTG GGCTGGGACTGTCTATGCCGACACTACTTTATGGTGGTGGAGCCACAGAGGGGCGGAACAA TGTGATGCCACAATCCACTCAATAAACATTTTCTGGTCCGCATACGGGCACACTCAATTTAC ACAGAATTTGTTCCACAGCCTCTCACCTCCTTCTAGGGCGCATTTTTCAACACTGGCCCTTCA AATTTAAAGCCTACGGAATACGGACGGTCGAGAAAGCGAGGTGGTCGGATTTGCCCTGGAA GGCAAAGAAAGAGTAGAGAAC

GCCATATTGAGTCGCCTCTCTCATCAGATTTACATTGACCATGTCCCCACCACTTATGGCATC CTTTAACTTTTCACCAAAACTTTTTTCAATGAGAGCAGATGGTATTGTTATGTTCTCTATGTA TTTTGCTGACGATCCATCCTCTTCAGGTGTGTCCATAGTTATTAAGGGTTCCTCAATATCATC TGCAACAAGAACCGCAGAAGCTCCAGCCTTCTGTGCATTCCAGACCTTGAGAGCAAAGAAA CAATCTGAAAAGGAACACACGAAAGCACAGGGAATACACACATGAGATAACATTTGAAGG CGTGGTAGCCATTGTTGAGTGGAAAGGGGGAGAAACAACGTGAACTGCCGAGGCTGACGG GTAGCTACTAGGAAAAAGGTGACCCGCAGTATGCTCAGCCAATCTTTTAATATAAGAATTAT GATTCAGTGATTTATCTCGGATATTTGACACAAACACGCACCTCACACGAGAAGTGCACTCT CCAAGAAAAGTGCCCTTGAATAGCTGCTGGTTCCAGTATACGCGGCCTCCGCGGAGTCGGA GTGGGCGAAGGTGGAACGGGACCTCGAATT

GCATTATCGTCCGCGTGTCGCAAGCTTCTTTTCTCTTTGGACCTCTCCCTCGATGCGGGTGGC GCTTGGGTAATACGACCAATCCATCACTGGCGCGCACTTCTCTTCGGAGCAGGGCTGACCGG ACCCATGCTGGGACCCTGCTTCACCGGCGCTTTCCTGCGGCCTCCGGAAATTCACTGGTTGA TACGACTGGTCTTGCCCATGCTCTACCTGGGCAATGGCTTCCCCCGCTACTCCCTGCCCCATG ACATGCTGTCCGGACCCGGGCTCCCGTTTGCCGACTACCTGATGAATGCCTCTCCCATGGCC AGCACTAGCGATGACTTCTTCATCTTTCACGTGATCTTCCCGGCTTACGGATTGTCCCCCGCC TGTAATTGGCCCACATCCTGCTCATCCCGCTGCTGCTCCTAGGGTGGCGGGCCGCTCATCTC TCTCTGGACTTCTACCGCCGCCACACCCCTCACCCGAGAGGCGGACGCACCAAGAAAAAGG CTCCCACATGCCCGCTGTTTTGAGTATATGCGATGGAGGGCGTGGCCCCCGGTGG

Figure 7: DNA sequences: a) SCoT-5 fragment collected from Wadi El-Rayan region (578 bp), b) SCoT-20 fragment collected from Ain Shams University region (585 bp) and c) SCoT-21 fragment collected from El-Dakhla Oasis region (553 bp) of Alhagi graecorum. 
Table 9: Showing the homology, identity, coverage and accession numbers of some SCoT markers.

\begin{tabular}{|c|c|c|c|c|}
\hline $\begin{array}{l}\text { Fragment } \\
\text { name }\end{array}$ & Homology & Identity & Coverage & $\begin{array}{l}\text { Accession } \\
\text { number }\end{array}$ \\
\hline \multirow{3}{*}{ SCoT-5 } & $\begin{array}{l}\text { Lupinus angustifolius cultivar Tanjil } \\
\text { chromosome LG-11 }\end{array}$ & $82.61 \%$ & $12 \%$ & СР023123.1 \\
\hline & $\begin{array}{l}\text { Vigna unguiculata cultivar Xiabao } 2 \\
\text { chromosome Vu03 }\end{array}$ & $89.47 \%$ & $8 \%$ & СР039346.1 \\
\hline & $\begin{array}{l}\text { Vigna unguiculata cultivar Xiabao } 2 \\
\text { chromosome Vu10 }\end{array}$ & $82.93 \%$ & $7 \%$ & СР039352.1 \\
\hline \multirow{3}{*}{ SCoT-20 } & $\begin{array}{l}\text { Lupinus angustifolius cultivar Tanjil } \\
\text { chromosome LG-04 }\end{array}$ & $82.52 \%$ & $56 \%$ & СР023116.1 \\
\hline & $\begin{array}{l}\text { Lotus japonicus genomic DNA, } \\
\text { chromosome 5, clone: LjT47L09, TM0218, } \\
\text { complete sequence }\end{array}$ & $85.71 \%$ & $51 \%$ & АР006374.1 \\
\hline & $\begin{array}{l}\text { Lupinus angustifolius cultivar Tanjil } \\
\text { chromosome LG-08 }\end{array}$ & $85.67 \%$ & $51 \%$ & СР023120.1 \\
\hline \multirow{3}{*}{ SCoT-21 } & Cytochrome b6 [Medicago truncatula] & $25 \%$ & $56 \%$ & RHN38456.1 \\
\hline & Cytochrome b6 apoprotein [Pisum sativum] & $28.89 \%$ & $48 \%$ & AAD41888.1 \\
\hline & $\begin{array}{l}\text { hypothetical protein GLYMA_01G058600 } \\
\text { [Glycine max] }\end{array}$ & $27.78 \%$ & $48 \%$ & KRH75043.1 \\
\hline
\end{tabular}

Table 10: Base frequency and length of sequenced region of SCoT-5, SCoT-20 and SCoT21 markers for the studied genotypes obtained from bulked DNA samples for different geographic regions.

\begin{tabular}{ccccccccccccc}
\hline $\begin{array}{c}\text { Fragments } \\
\text { name }\end{array}$ & \multicolumn{2}{c}{ A } & \multicolumn{2}{c}{ T } & \multicolumn{2}{c}{ G } & & C & AT & GC & $\begin{array}{c}\text { Total } \\
\text { length }\end{array}$ \\
\cline { 2 - 12 }$y$ & No. & \% & No. & \% & No. & \% & No. & \% & \% & \% & base \\
\hline SCoT5 & 128 & 22.1 & 134 & 23.1 & 151 & 26.1 & 165 & 28.5 & 45.3 & 54.7 & 578 \\
SCoT20 & 171 & 29.2 & 148 & 25.3 & 133 & 22.7 & 133 & 22.7 & 54.5 & 45.5 & 585 \\
SCoT21 & 84 & 15.2 & 134 & 24.2 & 139 & 25.1 & 196 & 33.5 & 39.4 & 60.6 & 553 \\
\hline Mean & & & & & & & & & $\mathbf{4 6 . 4}$ & $\mathbf{5 3 . 6}$ & $\mathbf{5 7 2}$ \\
\hline
\end{tabular}




\section{Assessment of genetic diversity}

sequences via GenBank and they reported that sequencing results of both mono- and some polymorphic amplicons have shown high identity between examined cultivars and the American T. aestivum L. cultivar Chinese spring (query cover 81-95\%). Also, Dhawan et al. (2013) compared the male-specific fragment of date palm (Phoenix dactylifera L.) which cloned and sequenced (GenBank accession number JN123357) and didn't show homology to any database sequence on BLASTn search (http://www.ncbi. nlm.nih.gov/Blast.cgi).

The GC content of SCoT5, SCoT20 and SCoT21 primers are 54.7, 45.5 and $60.6 \%$, respectively with average percentage 53.6\%; while the AT content in all fragments was 45.3, 54.5 and 39.4\%, respectively with average percentage 46.4 , also the total length of SCoT5, SCoT20 and SCoT21 was varied 578, 585 and 553 bp, respectively with a mean length 572 bp (Table 10). The average GC content was higher than many previous studies for different plants, such as Echinochloa phyllopogon (Chen et al., 2017), Phoenix dactylifera (Dhawan et al., 2013) and Pogostemon cablin (Kumar et al., 2016) was 45.8\%, $34.5 \%$ and 28.49\%, respectively. Also, Smarda et al. (2014) studied GC content in 239 different plant genomes, finding that the GC content of monocots varied between $33.6 \%$ and $48.9 \%$, and increased GC content was documented in species able to grow in seasonally cold and/or dry climates. Furthermore, Wang et al. (2019) observed that a scatterplot of the genomic GC of Acer truncatum content and sequencing depth can provide information on sequencing data bias. The GC content of Acer truncatum genome was $35.04 \%$. In the present results at the 3 alignment levels it can be concluded that; the highest values of identity SCoT-5 (89.47\%) followed by SCoT-20 (85.71\%) were recorded but the minimum value was in SCoT-21 (25\%). The largest percentage of coverage was found in both SCoT-20 and SCoT-21 (56\%), while the lowest percentage of coverage was $7 \%$ in SCoT-5 (Table 9). The mean percentage of AT and GC content for SCoT sequences primers was recorded 46.4 and 53.6, respectively with a mean total length 572bp (Table 10).

\section{CONCLUSION}

The present study is the first detailed report of genetic relationships among and within Alhagi genotypes collected from different geographical regions using genetargeted SCoT markers. The present results revealed a high polymorphic percentage with high molecular variation within populations (52\%) more than among them (48\%). In addition, the GC average percentage of three clearly unique bulkedDNA bands was 53.6\%. In conclusion, the SCoT marker system provides a highly efficient, reproducible and powerful tool for studying the genetic diversity for $A$. graecorum populations.

\section{REFERENCES}

Abdel-Lateif, K. S. and Hewedy, O. A. (2018) Genetic diversity among Egyptian wheat cultivars using SCoT and ISSR markers. SABRAO Journal of Breed Genetics, 50, 36-45.

Abdel-maksoud, R., Ageez, A., ElKhishin, D., Fahmy, E. and AbdelTawab, F. (2009) Differential Gene Expression in Response to Salt Stress in Vicia monantha. Egyptian Journal of Genetics and Cytology, 38: 137-152.

Adawy, S.S., Ibrahim, S.D. Sayed, A.I. and El-Morsy S.I. (2010) Construction of Microsatellite Library from Date Palm (Phoenix dactylifera L.) for Isolation and Characterization of SSR Markers. Journal of Biotechnology Research, 10, 23-38.

Adawy, S.S., Diab, A.A., Sayed, A.I., Ibrahim, S.D., El-Morsy, S.I. and Saker, M.M. (2013) construction of genetic linkage map and qtl analysis of net blotch 
resistance in barley. International Journal of Advanced Biotechnology and Research, 4 (3) 348-363.

Agarwal, A., Gupta, V., Haq, S. U., Jatav, P. K., Kothari, S. L. and Kachhwaha, S. (2018) Assessment of genetic diversity in 29 rose germplasms using SCoT marker. Journal of King Saud University-Science, In press, corrected proof, Available online 17 April 2018.

Ahmed, M. A. (2019) Protective effect of aqueous extract of Alhagi maurorum in spermatogenesis and antioxidant status of adult rats exposed to carbon tetrachloride. Iraqi Journal of Veterinary Sciences, 33(1), 1-7.

Alikhani, L., Rahmani, M. S., Shabanian, N., Badakhshan, $H$. and Khadivi-Khub, A. (2014) Genetic variability and structure of Quercus brantii assessed by ISSR, IRAP and SCoT markers. Gene, 552(1), 176-183.

Al-Qurainy, F., Khan, S., Nadeem, M. and Tarroum, M. (2015) SCoT marker for the assessment of genetic diversity in Saudi Arabian date palm cultivars. Pakistan Journal of Botany, 47(2), 637-643.

Amirmoradi, B., Talebi, R. and Karami, E. (2012) Comparison of genetic variation and differentiation among annual Cicer species using start codon targeted (SCoT) polymorphism, DAMD-PCR, and ISSR markers. Plant systematics and evolution, 298(9), 1679-1688.

Badshah, L. and Hussain, F. (2011) People preferences and use of local medicinal flora in District Tank, Pakistan. Journal of Medicinal Plants Research, 5(1), 22-29.

Bhattacharyya, P., Kumaria, S., Kumar, S. and Tandon, P. (2013) Start Codon Targeted (SCoT) marker reveals genetic diversity of Dendrobium nobile Lindl., an endangered medicinal orchid species. Gene, 529(1), 21-26.

Biswas, A., Bari, M. A., Roy, M. and Bhadra, S. K. (2010) Inherited folk pharmaceutical knowledge of tribal people in the Chittagong hill tracts. Bangladesh, 9(1): 77-89

Bornet, B. and Branchard, M. (2001) Nonanchored inter simple sequence repeat (ISSR) markers: reproducible and specific tools for genome fingerprinting. Plant molecular biology reporter, 19(3), 209215.

Boulos, L. (1966) Flora of the Nile Region in Egyptian Nubia. Journal of Botanical Taxonomy and Geobotany, 73(3), 184-215. Charlesworth, D. and Wright, S. I. (2001) Breeding systems and genome evolution. Current opinion in genetics \& development, 11(6), 685-690.

Chen, G., Zhang, W., Fang, J. and Dong, L. (2017) Identification of massive molecular markers in Echinochloa phyllopogon using a restriction-site associated DNA approach. Plant diversity, 39(5), 287-293.

Collard, B. C. and Mackill, D. J. (2009)

Start codon targeted (SCoT) polymorphism: a simple, novel DNA marker technique for generating genetargeted markers in plants. Plant molecular biology reporter, 27(1), 86.

Dhawan, C., Kharb, P., Sharma, R., Uppal, S. and Aggarwal, R. K. (2013) Development of male-specific SCAR marker in date palm (Phoenix dactylifera L.). Tree genetics \& genomes, 9(5), 11431150.

Dice, L.R. (1945) Measures of the amount of ecologic association between species. Ecology 26:297-302.

Doyle, J.J. and Doyle, J.L. (1990) Isolation of plant DNA from fresh tissue. Focus, 12: 13-15.

Gorji, A. M., Poczai, P., Polgar, Z. and Taller, J. (2011) Efficiency of arbitrarily amplified dominant markers (SCoT, ISSR and RAPD) for diagnostic fingerprinting in tetraploid potato. American journal of potato research, 88(3), 226-237. 


\section{Assessment of genetic diversity}

Gower, J.C. (2015) Principle coordinates analysis. Wiley StatsRef: Statistics Reference Online.

Guo, D. L., Zhang, J. Y. and Liu, C. H. (2012) Genetic diversity in some grape varieties revealed by SCoT analyses. Molecular biology reports, 39(5), 53075313.

Hamidi, H., Talebi, R. and Keshavarzi, F. (2014) Comparative efficiency of functional gene-based markers, start codon targeted polymorphism (SCoT) and conserved DNA-derived polymorphism (CDDP) with ISSR markers for diagnostic fingerprinting in wheat (Triticum aestivum L.). Cereal research communications, 42(4), 558-567.

Hammer, Ø., Harper, D. A. T. and Ryan, P. D. (2001) PAST: Paleontological statistics software package for education and data analysis. Palaeontologia Electronica, 4(1), 4-9.

Hamrick, J.L. and Godt, M.J.W. (1996) Effects of life history traits on genetic diversity in plant species. Phil Trans $R$ Soc Lond, 351:1291-1298.

Lovejoy, T. E. and Hannah, L. J. (2005) Climate change and biodiversity. (Eds.) Yale university press, New Haven and London.

Hao, J., Jiao, K., Yu, C., Guo, H., Zhu, Y., Yang, $X$. and Dong, $M$. (2018) Development of SCoT-Based SCAR marker for rapid authentication of Taxus Media. Biochemical genetics, 56(3), 255266.

Heikrujam, M., Kumar, J. and Agrawal, V. (2015) Genetic diversity analysis among male and female Jojoba genotypes employing gene targeted molecular markers, start codon targeted (SCoT) polymorphism and CAAT box-derived polymorphism (CBDP) markers. Meta gene, 5, 90-97.

Henry, R. J. (1998) Molecular and biochemical characterization of somaclonal variation. In Somaclonal variation and induced mutations in crop improvement (pp. 485-499). Springer, Dordrecht.
Ibrahim, S.D., Adawy, S.S., Atia, M.A.M., Alsamman, M.A. and Mokhtar M.M. (2016) Genetic diversity, variety identification and gene detection in some Egyptian grape varieties by SSR and SCoT markers. POJ, 9(5): 311-318.

Igwe, D. O., Afiukwa, C. A., Ubi, B. E., Ogbu, K. I., Ojuederie, O. B. and Ude, G. N. (2017) Assessment of genetic diversity in Vigna unguiculata L. (Walp) accessions using inter-simple sequence repeat (ISSR) and start codon targeted (SCoT) polymorphic markers. BMC genetics, 18(1), 98.

Jack Masquelier, E. (1996) Oligomeric proanthocyanidins (OPCs) are the heart of the French paradox. Townsend Letter for Doctors and Patients, 46-49.

Javouhey, M., Daguin, F. and Letouze, $R$. (2000) Somatic embryogenesis, an efficient tool for date palm (Phoenix dactylifera L.) industrial micropropagation. Characterization and genetic stability of original offshoots and regenerated plantlets by RAPD markers. In International Symposium on Methods and Markers for Quality Assurance in Micropropagation 530 (pp. 237-242).

Jiang, L. F., Qi, X., Zhang, X. Q., Huang, L. K., Ma, X. and Xie, W. G. (2014) Analysis of diversity and relationships among orchardgrass (Dactylis glomerata L.) accessions using start codon-targeted markers. Genetics and Molecular Research, 13(2), 4406-4418.

Khan, F. M. (2009) Ethno-veterinary medicinal usage of flora of Greater Cholistan desert (Pakistan). Pakistan Veterinary Journal, 29(2), 75-80.

Kordrostami, M. and Rahimi, M. (2015). Molecular markers in plants: concepts and applications. G3M, 13, 4024-4031.

Kumar, D., Kalra, A. B. A. and Dobriyal, M. J. (2016) Effect of Shade and Organic Manure on Growth and Yield of Patchouli [Pogostemon cablin (Blanco) Benth.] under Teak (Tectona grandis LF) Based Agroforestry System. Indian Forester, 142(11), 1121-1129. 
Kumar, J. and Agrawal, V. (2019) Assessment of genetic diversity, population structure and sex identification in dioecious crop, Trichosanthes dioica employing ISSR, SCoT and SRAP markers. Heliyon, 5(3), e01346.

Laghari, A. H., Memon, S., Nelofar, A. and Khan, K. M. (2012) Antifungal Ursene-Type Triterpene from the Roots of Alhagi camelorum. Helvetica Chimica Acta, 95(9), 1556-1560.

Luo, C., He, X. H., Chen, H., Ou, S. J. and Gao, M. P. (2010) Analysis of diversity and relationships among mango cultivars using Start Codon Targeted (SCoT) markers. Biochemical Systematics and Ecology, 38(6), 1176-1184.

Luo, C., He, X. H., Chen, H., Ou, S. J., Gao, M. P., Brown, J. S. and Schnell, R. J. (2011) Genetic diversity of mango cultivars estimated using SCoT and ISSR markers. Biochemical Systematics and Ecology, 39(4-6), 676-684.

Ma, X., Zhang, Q., Zhu, Q., Liu, W., Chen, Y., Qiu, R. and Xie, Y. (2015) A robust CRISPR/Cas9 system for convenient, high-efficiency multiplex genome editing in monocot and dicot plants. Molecular plant, 8(8), 1274-1284.

Mohamed, A. H., Ibrahim, M., Teleb, S.S. and Tantawy, M.E. (2017) SEM and SCoT Markers Unveil New Taxonomic and Genetic Insights about Some Northern African Triticum aestivum L.Cultivars. Vegetos- An International Journal of Plant Research, 30:1.

Muhammad, G., Hussain, M. A., Anwar, F., Ashraf, M. and Gilani, A. H. (2015) Alhagi: a plant genus rich in bioactives for pharmaceuticals. Phytotherapy research, 29(1), 1-13.

Pavoine, S., Dufour, A. B. and Chessel, D. (2004) From dissimilarities among species to dissimilarities among communities: a double principal coordinate analysis. Journal of theoretical biology, 228(4), 523537.
Poczai, P., Varga, I., Laos, M., Cseh, A., Bell, N., Valkonen, J. P. and Hyvönen, J. (2013) Advances in plant gene-targeted and functional markers: a review. Plant Methods, 9(1), 6. doi: 10.1186/1746-48119-6

Revathi, P. and Parimelazhagan, $T$. (2010) Traditional knowledge on medicinal plants used by the Irula tribe of Hasanur Hills, Erode District, Tamil Nadu, India. Ethnobotanical Leaflets, 2010(2),4.

Sadek M.S. and Ibrahim S.D. (2018) Genetic relationships among maize inbred lines as revealed by Start Codon Targeted (SCoT) analysis. Journal of Innovations in Pharmaceutical and Biological Sciences, 5 (1), 103-107.

Satya, P., Karan, M., Jana, S., Mitra, S., Sharma, A., Karmakar, P. G. and Ray, D. P. (2015) Start codon targeted (SCoT) polymorphism reveals genetic diversity in wild and domesticated populations of ramie (Boehmeria nivea L. Gaudich.), a premium textile fiber producing species. Meta gene, 3, 62-70.

Segarra-Moragues, J. G. and Catalán, P. (2002) Low Allozyme Variability in the Critically Endangered Borderea chouardii and in Its Congener Borderea pyrenaica (Dioscoreaceae), Two Paleoendemic Relicts from the Central Pyrenees. International Journal of Plant Sciences, 163(1), 159-166.

Semagn, K., Bjørnstad, $\AA$. and Ndjiondjop, M. N. (2006) An overview of molecular marker methods for plants. African journal of biotechnology, 5(25), 2540-2568.

Shahlaei, A., Torabi, S. and Khosroshahli, M. (2014) Efficacy of SCoT and ISSR markers in assessment of tomato (Lycopersicum esculentum Mill.) genetic diversity. International Journal of Biosciences, 5(2), 14-22.

Sivaprakash, K. R., Prashanth, S. R., Mohanty, B. P. and Parida, A. (2004) Genetic diversity of black gram (Vigna 


\section{Assessment of genetic diversity}

mungo) landraces as evaluated by amplified fragment length polymorphism markers. Current Science, 1411-1416.

Šmarda, P., Bureš, P., Horová, L., Leitch, I. J., Mucina, L., Pacini, E. and Rotreklová, O. (2014) Ecological and evolutionary significance of genomic GC content diversity in monocots. Proceedings of the National Academy of Sciences, 111(39), E4096-E4102.

Sneath, P. and Sokal, R. (1973) Numerical Taxonomy. San Francisco, California.

Szczecińska, M., Sramko, G., Wołosz, K. and Sawicki, J. (2016) Genetic diversity and population structure of the rare and endangered plant species Pulsatilla patens (L.) Mill in East Central Europe. PLoS One, 11(3), e0151730.

Talebi, R., Nosrati, S., Etminan, A. and Naji, A. M. (2018) Genetic diversity and population structure analysis of landrace and improved safflower (Cartamus tinctorious L.) germplasm using arbitrary functional gene-based molecular markers. Biotechnology \& Biotechnological Equipment, 32(5), 1183-1194.

Tiwari, G., Singh, R., Singh, N., Choudhury, D. R., Paliwal, R., Kumar, A. and Gupta, V. (2016) Study of arbitrarily amplified (RAPD and ISSR) and gene targeted (SCoT and CBDP) markers for genetic diversity and population structure in Kalmegh [Andrographis paniculata (Burm. f.) Nees]. Industrial Crops and Products, 86, 1-11.

Tyagi, A., Singh, S., Mishra, P., Singh, A., Tripathi, A. M., Jena, S. N. and Roy, S. (2016) Genetic diversity and population structure of Arabidopsis thaliana along an altitudinal gradient. AoB Plants, 8.

Wang, R., Fan, J., Chang, P., Zhu, L., Zhao, M. and Li, L. (2019) Genome Survey Sequencing of Acer truncatum Bunge to Identify Genomic Information, Simple Sequence Repeat (SSR) Markers and Complete Chloroplast. Genome, Forests 10, 87; doi:10.3390/f10020087.

Williams, J. G. K., Kubelik, A. R., Livak, K. J., Rafalski, J. A. and Tingey, S. V. (1990) DNA polymorphisms amplified by arbitrary primers are useful as genetic markers. Nucleic Acids Research, 18(22), 6531-6535.

Wyk, B.E. and Wink, M. (2004) Medicinal Plants of the World. Timber Press, Portland, OR, p. 188.

Xiong, F., Zhong, R., Han, Z., Jiang, J., He, L., Zhuang, W. and Tang, R. (2011) Start codon targeted polymorphism for evaluation of functional genetic variation and relationships in cultivated peanut (Arachis hypogaea L.) genotypes. Molecular biology reports, 38(5), 34873494.

Xue, W., Li, X. Y., Zhu, J. T. and Lin, L. S. (2012) Effects of temperature and irradiance on photosystem activity during Alhagi sparsifolia leaf senescence. Biologia plantarum, 56(4), 785-788.

Yan, H., Zhang, Y., Zeng, B., Yin, G., Zhang, $X .$, Ji, Y. and Ma, X. (2016) Genetic diversity and association of ESTSSR and SCoT markers with rust traits in orchardgrass (Dactylis glomerata L.). Molecules, 21(1), 66.

Yang, S., Xue, S., Kang, W., Qian, Z. and Yi, Z. (2019) Genetic diversity and population structure of Miscanthus lutarioriparius, an endemic plant of China. PloS one, 14(2), e0211471.

Zhang, J., Xie, W., Wang, Y. and Zhao, X. (2015) Potential of start codon targeted (SCoT) markers to estimate genetic diversity and relationships among chinese Elymus sibiricus accessions. Molecules, 20(4), 5987-6001.

Zhang, Y., Yan, H., Jiang, X., Wang, X., Huang, L., Xu, B. and Zhang, L. (2016) Genetic variation, population structure and linkage disequilibrium in Switchgrass with ISSR, SCoT and EST-SSR markers. Hereditas, 153(1), 4.

Zietkiewicz,E., Rafalski,A. and Labuda,D. (1994) Genome Fingerprinting by Simple Sequence Repeat (SSR)Anchored Polymerase Chain Reaction Amplification. Genomics, 20 (2), 176-183. Zou, G. A., Mansur, S., Hu, S. C., Aisa, H. A. and Shakhidoyatov, K. M. (2012) Pyrrole alkaloids from Alhagi sparsifolia. Chemistry of natural compounds, 48(4), 635-637. 